arteries (p < 0.03). Responses relative to $E_{\max }$ was, in 3 mo. old rats, $76 \pm 5 \%(10)$ and $62 \pm 9(8)$, and in 2 y. old rats, $85 \pm 3 \%(10)$ and $75 \pm 10 \%(G)$, for proximal and distal arteries, respectively. The rat coronary artery 5-HT sensitivity increased by a factor of $5(p<0.001)$ in arteries from old rats, however there was no difference in sensitivity between proximal and distal arteries. The change in vascular 5-HT sensitivity was accompanied by a larger increase in $K_{A}$, $1.5 \cdot 10^{-6} \mathrm{M}$ to $2 \cdot 10^{-7} \mathrm{M}$ in vessels from young and old rats, respectively. $\mathrm{K}_{\mathrm{A}}$ was similar in proximal and distal arteries. The relative receptor occupancy for half maximal 5-HT response increased with age in both proximal and distal vessels $(p<0.03)$ and was greater $(p<0.02)$ in distal than proximal ones. The difference between $-\log \left(E C_{50}(M)\right)$ and $-\log \left(K_{A}(M)\right)$ was $>$ zero on average in any type of vessel. The slope of the regression line of plots of $-\log \left(\mathrm{K}_{\mathrm{A}}(\mathrm{M})\right)$ vs. $-\log \left(\mathrm{EC}_{50}(\mathrm{M})\right)$ was ecoual to unity for the dictol arteries at boin ages studied. Tine slope of this regression line was in contrast different from unity for the proximal arteries at both ages. The reiative receptor occupancy, which may be taken as an indirect measure of the receptor density, and affinity, $-\log \left(K_{A}(M)\right)$ was linear correlated ( $p<0.01$ ), the affinity being lower in vessels with a large receptor reserve, $\mathbf{R}_{A} / \mathbf{R}_{T}$ low, than in vessels with a low receptor reserve. Ach induced equal relaxation in all vessel groups.

The results indicate that rat coronary artery 5-HT sensitivity increases with age due to an increase in $\mathrm{K}_{\mathrm{A}}$. The concomitant reduction in receptor reserve with ageing counteracts the increase in 5-HT receptor affinity regarding vessel 5-HT sensitivity. The greater response to 5-HT despite the reduced receptor reserve in old rats suggests a more efficient E-C coupling process in these rats. The 5-HT receptor affinity seems to be counterregulated by the receptor density in proximal rat coronary arteries, which might be an important physiological mechanism hindering inapropriate coronary vasoconstriction by $5-\mathrm{HT}$.

\title{
Reference
}

Nyborg, N.C.B. and Mikkelsen, E.O., Cardiovasc. Res. 22: 131-7, 1988.

P.we.120

\section{The effects of sumatriptan on the carotid circulation of the pig}

\author{
den Boer, M.O., Villalón, C.M., Heiligers, J.P.C., Saxena, P.R. and Humphrey *, P.P.A. \\ Department of Pharmacology, Erasmus University Rotterdam, P.O. Box 1738, 3000 DR Rotterdam, The Netherlands and * Glaxo Group \\ Research, Ware, U.K.
}

Sumatriptan (GR43175) is a selective agonist at the $5-\mathrm{HT}_{1}$-like receptor mediating contraction of the dog saphenous vein and the dog, primate and human basilar artery. The drug has been found effective in the sreatment of acute migraine attacks (see Humphrey et al., 1989; Saxena and Ferrari, 1989). Since 5-HT - -like receptors also mediate the constriction of arteriovenous anastomoses (AVAs) as well as the dilatation of arterioles in the pig carotid circulation (Saxena et al., 1989), the present experiments were devoted to the study of the craniovascular effects of sumatriptan $\left(10,30,100\right.$ and $\left.300 \mu \mathrm{g} \cdot \mathrm{kg}^{-1}\right)$ in pentobarbital-anaesthetized pigs (16-19 $\left.\mathrm{kg}\right)$. The radioactive microsphere technique was employed to measure the fractionation of common carotid blood flow into AVA and nutrient parts (Saxena et al., 1989).

As shown in Table 1, sumatriptan decreased dose dependently carotid vascular conductance (CVC) up to $33 \pm 9 \%$ and its AVA fraction (AVAC) up to $66 \pm 10 \%$ at the highest dose used. These decreases remained unchanged after ketanserin $\left(0.5 \mathrm{mg} \cdot \mathrm{kg}^{-1}\right)$ but were significantly attenuated by methiothepin $\left(1 \mathrm{mg} \cdot \mathrm{kg}^{-1}\right)$. Sumatriptan increased the over-all nutrient conductance (NC) by $54 \pm 18 \%$; this increase was noticed in the ears, head skin, tongue, fat and bones. Methiothepin tended to attenuate this increase as well. Sumatriptan had no influence on mean arterial blood pressure, but a small decrease in heart rate was observed during the experiments. 
Table 1

Carotid haemodynamic variables of sumatriptan $\left(\mu \mathrm{g} \cdot \mathrm{kg}{ }^{-1}\right)$ after pretreatment with saline, ketanserin $\left(0.5 \mathrm{mg} \cdot \mathrm{kg}^{-1}\right)$ or methiothepin (1 $\left.\mathrm{mg} \cdot \mathrm{kg}^{-1}\right)$.

\begin{tabular}{|c|c|c|c|c|c|c|}
\hline Pretreatment & 0 & 10 & 30 & 100 & 300 & \\
\hline $\begin{array}{l}\text { Saline } \\
(n=8)\end{array}$ & $\begin{array}{l}\text { CVC } \\
\text { AVAC } \\
\text { NC }\end{array}$ & $\begin{array}{r}200 \pm 30 \\
158 \pm 27 \\
44 \pm 5\end{array}$ & $\begin{array}{c}180 \pm 20 \\
135 \pm 22 * \\
46 \pm 5\end{array}$ & $\begin{array}{c}150 \pm 20 * \\
109 \pm 23 * \\
43 \pm 5\end{array}$ & $\begin{array}{r}140 \pm 20^{*} \\
80 \pm 21 * \\
59 \pm 7 \text { * }\end{array}$ & $\begin{array}{r}120 \pm 20^{*} \\
54 \pm 18 \text { * } \\
67 \pm 10^{*}\end{array}$ \\
\hline $\begin{array}{l}\text { Ketanserin } \\
(\mathbf{n}=\mathbf{6})\end{array}$ & $\begin{array}{l}\text { CVC } \\
\text { AVAC } \\
\text { NC }\end{array}$ & $\begin{array}{c}270 \pm 30 \\
21 \pm \pm 31 \\
52 \pm 3\end{array}$ & $\begin{array}{c}240 \pm 30 \\
184 \pm 31 * \\
57 \pm 6\end{array}$ & $\begin{array}{c}210 \pm 30 * \\
145 \pm 26 * \\
63 \pm 8\end{array}$ & $\begin{array}{r}180 \pm 30^{*} \\
108 \pm 29 * \\
72 \pm 8 *\end{array}$ & $\begin{array}{r}160 \pm 30^{*} \\
87 \pm 31 * \\
69 \pm 14^{*}\end{array}$ \\
\hline $\begin{array}{l}\text { Methiothepin } \\
(\mathbf{n}=7)\end{array}$ & $\begin{array}{l}\text { CVC } \\
\text { AVAC } \\
\text { NC }\end{array}$ & $\begin{array}{r}200 \pm 20 \\
163 \pm 16 \\
33 \pm 4\end{array}$ & $\begin{array}{c}190 \pm 20 \\
161 \pm 14 \\
33 \pm 4\end{array}$ & $\begin{array}{c}180 \pm 20= \\
152 \pm 15= \\
33 \pm 4\end{array}$ & $\begin{array}{c}170 \pm 10 * \# \\
127 \pm 13 * \# \\
39 \pm 5^{*}\end{array}$ & $\begin{array}{c}150 \pm 20 * \\
101 \pm 15 * \\
45 \pm 5 *\end{array}$ \\
\hline
\end{tabular}

Values are presented as mean \pm s.e. mean; $\mathrm{CVC}=$ carotid vascular conductance; $\mathrm{AVAC}=$ arteriovenous anastomotic conductance; $\mathrm{NC}=$ nutrient conjuctance (all conductances in $\mathrm{ml} \cdot \mathrm{min}^{-1} \cdot \mathrm{mmHg}^{-1} ;{ }^{*}, \mathrm{P}<0.05$ vs baseline; ${ }^{*}, \mathrm{P}<0.05$ vs changes in saline pretreated group.

We conclude that sumatriptan constricts cranial AVAs in the pig by an agonist action at a 5-HT - -like receptor. This

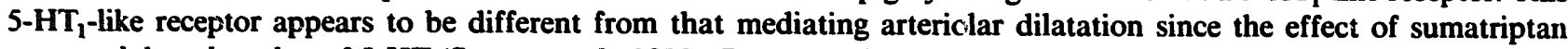
was much less than that of 5-HT (Saxena et al., 1989). The constriction of arteriovenous anastomoses, as observed with several other anti-migraine drugs (Saxena et al., 1989), could be a factor in the relief of symptoms during acute attacks.

\title{
References
}

Humphrey, P.P.A., Feniuk, W., Perren, M.J., Connor, H.J., Oxford, A.W., 1989, Cephalalgia 9 (suppl. 9), 23.

Saxena, P.R. and Ferrari, M.D., 1989, Trends Pharmacol. Sci. 10, 200.

Saxena, P.R., Bom, A.H. and Verdouw, P.D., 1989, Cephalalgia 9 (suppl. 9), 15.

P.we.121

\section{Sex hormone status modulates response to serotonin in isolated rabbit basilar artery}

\author{
Moss, J., Futo, J., Block, S., Beach, M., Holt, J.A. and Finn, R. \\ Departments of Anesthesia and Critical Care, Surgery, and Obstetrics and Gynecology, the University of Chicago, Chicago, IL 60637 \\ U.S.A.
}

Delayed vasospasm following rupture of cerebral aneurysm is more common in postmenopausal women than in men. Similarly, migraine headache is related to gender and menstrual status and is altered by serotonin (5HT) agonists. To study these phenomena we created an animal model by utilizing isolated basilar artery segments from rabbits, on which different hormonal states were imposed, and measured the response to 5HT and norepinephrine (NE).

Methods: Juvenile female rabbits were assigned into three groups: oophorectomized control $(\mathrm{n}=10)(0)$; superovulated pseudopregnant estrogen-stimulated, (i.e. high estrogen and progesterone levels) $(n=5)(H)$; superovulated pseudopregnant estrogen-deprived for 48 hours, (i.e., rapid fall in progesterone level and decline in estrogen) $(n=4)(W)$. Oophorectomy was performed in group $0,10-15$ days before the experiment. In group $\mathrm{H}$ and $\mathrm{W}$, we used the pseudopregnancy model, which simulated the second (luteal) phase of the menstrual cycle. Superovulation and pseudopregnancy were induced in rabbits by hormonal treatment and insertion of estrogen-filled capsule (Holt, 1981). Progesterone and estrogen levels were measured by radioimmunoassay. The rabbits were killed by decapitation under pentobarbital anesthesia. The basilar artery with intact endothelium (verified by responsiveness to acetylcholine) was then dissected and cut into 3-4 mm rings under an operating microscope. The rings were mounted on stainless steel hooks and allowed to equilibrate with aerated Krebs-Ringer buffer for $1 \mathrm{~h}$ at $0 \mathrm{mg}$ preload. Isometric tension was 